\title{
Evolution of Post in region of Žilina
}

\author{
Ing. Jozef Fabuš \\ Department of communication \\ University of Žilina \\ Univerzitná 1 Žilina, Slovakia
}

\author{
Ing. Iveta Kremeňová, \\ Department of communication \\ University of Žilina \\ Univerzitná 1 Žilina, Slovakia
}

\begin{abstract}
Paper deals with local problem of post deployment in region of Žilina. It compares numbers of delivery zones, posts, mailboxes and post compartment. We used several ratios about comparison of selected indicators. In the end we describe our opinion on situation of post evolution in region of Žilina.
\end{abstract}

Keywords: Post, postal indicators, postal ratios, post usability coefficient, delivery zone coefficient, mailboxes coefficient, post compartment coefficient (Minimum 5 to 8 key words)

\section{INTRODUCTION}

We have selected 4 indicators that we use for several ratios to consider evolution of post in region of Žilina

Table 1. Selected indicators for post by regions, type of indicator and year

\begin{tabular}{|c|c|c|c|c|c|c|c|c|}
\hline \multicolumn{7}{|c|}{ Selected indicators for post by regions, type of indicator and year } \\
\cline { 2 - 9 } & 2008 & 2009 & 2010 & 2011 & 2008 & 2009 & 2010 & 2011 \\
\hline $\begin{array}{c}\text { Region } \\
\text { of Žilina }\end{array}$ & 646 & 640 & 634 & 631 & 183 & 183 & 184 & 182 \\
\hline & \multicolumn{3}{|c|}{ Mailboxes } & \multicolumn{5}{c|}{ Post compartment } \\
\hline $\begin{array}{c}\text { Region } \\
\text { of Žilina }\end{array}$ & 2008 & 2009 & 2010 & 2011 & 2008 & 2009 & 2010 & 2011 \\
\cline { 2 - 9 } & 807 & 783 & 774 & 684 & 413 & 398 & 395 & 391 \\
\hline
\end{tabular}

\subsection{Delivery zones}

Delivery zones in Slovak republic are selected by geographical plan of Slovak national postal operator. Evolution of delivery zones in region Žilina by numbers is illustrated in left-upper corner of table 1.

\subsection{Posts}

Posts indicator means point of possibility to make submission and delivery of mails. It is presented mostly by building owned by Slovak national post operator. Evolution of posts in region Žilina by numbers is illustrated in right-upper corner of table 1.

\subsection{Mailboxes}

People often made a mistake when thinks mailboxes are boxes they have at home, that are homeboxes. Mailboxes are place, where a postman collects mail. Evolution of mailboxes in region of Žilina by numbers is illustrated in left-bottom corner of table 1 .

\subsection{Post compartment}

It is a place where customers came to submit their mail. They are directly placed in Posts. Evolution of post compartments in Žilina by numbers is illustrated on right-bottom corner of table 1 .

\section{Ratios}

In this section of paper we deal with 3 basic coefficients and one complex coefficient of post usability.

\subsection{Delivery zone coefficient}

(1) compares number of posts with number of delivery zones. In this way we get ratio of current status of post usability by delivery zone.

$$
D Z C=\frac{P}{D Z} * 100
$$

Evolution of ratio (1) is illustrated on figure 1.

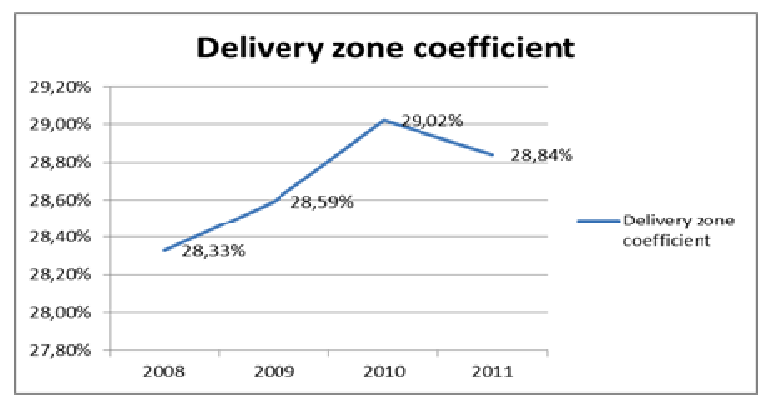

Figure 1. Delivery zone coefficient.

\subsection{Malboxes coefficient}

(2) compares number of posts with number of mailboxes. In this way we get ratio of current status of post usability by mailbox.

$$
M B C=\frac{P}{M B} * 100
$$

Evolution of ratio (2) is illustrated on figure 2.

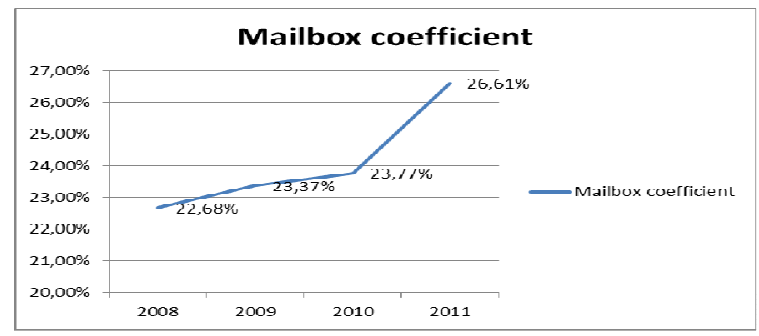

Figure 2. Mailbox coefficient. 


\subsection{Post compartment coefficient}

(3) compares number of posts with number of delivery zones. In this way we get ratio of current status of post usability by post compartment.

$$
P C C=\frac{P}{P C} * 100
$$

Evolution of ratio (3) is illustrated on figure 3.

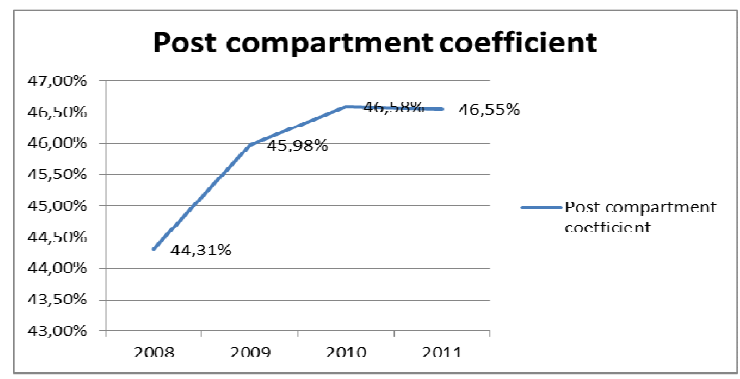

Figure 3. Post compartment coefficient.

\subsection{Post usability coefficient}

(4) is applied to create an overall image of post usability in selected region/sector. The values for quantification of selected indicators were determinate on individual experiences and needs.

$$
P U C=\frac{(P C+D Z / 2+M B / 3)}{6 P} * 100
$$

Ideal value is $\mathrm{PUC}=100 \%$. Possibilities to reach a $100 \%$ value are only theoretical. Acceptable values are from $90 \%$ above. Values in region of Žilina are illustrated on figure 4. Post usability coefficient in region of Žilina is decreasing; our reaction is situated in Conclusion.

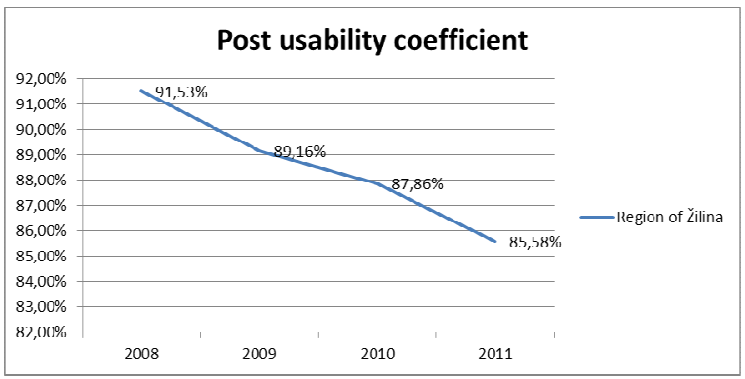

Figure 4. Post usability coefficient.

\section{Conclusion}

From figures 1-3 we can infer conclusion that post sector in Žilina is evolving in good way, because this generation of customers are not satisfied with direct contact. They rather do everything contactless and when we compare figure 2 . and figure 3., we deduce that evolution is aimed at reducing direct contact of customers with postal operator. The problem we discover is that Slovak national post operator in region of Žilina is decreasing numbers of mailboxes, delivery zones and post compartments, but numbers of posts remain the same.
We have reached an opinion that Slovak national post operator should decrease number of posts in region of Žilina. Slovak national post operator can gain a profit from rental useless buildings.

\section{ACKNOWLEDGMENTS}

Our thanks to the experts who have agree to discuss with us about our findings

\section{REFERENCES}

[1] G. Mokošová, J. Štofková, Pošta a komunikačná infraštruktúra, In: Hospodárske noviny., ISSN 08629567., 1995, volume 109, p.8.

[2] T. Čorejová, Territory post and telecommunication under investigation, In: Communications - scientific letters of the University of Žilina., ISSN 1335-4205, 2002, volume $1-2$, p.24-32.

[3] Regdat, http://px-web.statistics.sk/PXWebSlovak/

[4] I. Kremeňová, T. Čorejová, Postal Information System for Public, In: TRANSCOM '97., ISBN 80-7100-415-4., 1997, p 157-160.

[5] Dumas, J.S. and Redish, J.C. (1999). A Practical Guide to Usability Testing (revised ed.), Bristol, U.K.: Intellect Books.

[6] Lund, A. M. (1997). Expert ratings of usability maxims. Ergonomics in Design, 5(3), 15-20. A study of the heuristics design experts consider important for good design.

[7] Holm, Ivar (2006). Ideas and Beliefs in Architecture and Industrial design: How attitudes, orientations, and underlying assumptions shape the built environment. Oslo School of Architecture and Design. ISBN 82-5470174-1.

[8] Donald A. Norman (2002), The Design of Everyday Things, Basic Books, ISBN 0-465-06710-7

[9] Jakob Nielsen (1994), Usability Inspection Methods, Morgan John Wiley \& Sons, ISBN 0-471-01877-5

[10] Nielsen, Jakob. Usability Inspection Methods. New York, NY: John Wiley and Sons, 1994

[11] Dorn, Harold; MacClellan, James E. (2006). Science and Technology in World History: An Introduction. Johns Hopkins University Press. ISBN 0-8018-8359-8.

[12] J. Baricová, A. Košt’álová, Analysis of company Slovenská pošta a.s., Bachelor thesis., University of Žilina: 2010, 56p.

[13] M. Kušvara, M. Tkáč, Mobile post - change of methods of providing postal services, Diploma Thesis., University of Žilina, 2006, 74p.

[14] A. Velochová, K. Štofková, Profitability comparison of classic post of Slovenska pošta, a. s. and post partner. Bachelor thesis., University of Žilina, 2011, 60p.

\section{Grant support}

This contribution was undertaken, as parts of the research projects: VEGA 1/0199/11- Research on interoperability of management techniques with the strategic objectives of the organization and KEGA 052ŽU-4/2012 On-line learning management in the process of ICT education. 